\title{
MODEL RAD DALAM PERANCANGAN FRONT END APLIKASI PAYMENT POINT ONLINE BANK (PPOB) BERBASIS ANDROID
}

\author{
Dian Ambar Wasesha1; Frieyadie ${ }^{2}$ \\ Sistem Informasi ${ }^{1,2}$ \\ STMIK Nusa Mandiri ${ }^{1,2}$ \\ http://www.nusamandiri.ac.id/1,2 \\ dian.dbw@nusamandiri.ac.id ${ }^{1}$, frieyadie@nusamandiri.ac.id ${ }^{2}$
}

\begin{abstract}
The conventional purchase of credit by sending sms to the agent server is often has problem. The error was caused by different format of SMS for each server. This error has an impact on the high cost of using SMS. Another problem when the customer wants to check the electricity bill, the website provided by PLN is less attractive or have to come directly to the PLN payment counter. With these problems, an Android-based application was developed to provide convenience in purchasing credit without worrying about writing format errors and checking until payment of various types of bills becomes more efficient. Bill payments become more practical in one unit, so there is no need to go to different payment counters each month and not get stuck in a long queue that wash time. Development model of this PPOB application is RAD which consists of business modeling, data modeling, process modeling, application development and testing.
\end{abstract}

Keywords: PPOB, Electonic Payment, Digital Wallet, $R A D$.

Intisari-Sistem pembelian pulsa konvensional dengan cara mengirim sms ke server agen sering terjadi kesalahan. Kesalahan ini karena format penulisan tiap - tiap server berbeda sehingga sulit diingat. Kesalahan ini berdampak pada biaya penggunaan SMS yang tinggi. Begitupun dengan pengecekan tagihan listrik, terkendala dengan kurang diminatinya website yang telah disediakan oleh PLN atau harus datang langsung ke loket pembayaran PLN. Dengan permasalahan tersebut maka dikembangkanlah suatu aplikasi berbasis android untuk memberikan kemudahan dalam pembelian pulsa tanpa khawatir terdapat kesalahan format penulisan dan pengecekan sampai pada pembayaran berbagai jenis tagihan menjadi lebih efisien. Pembayaran tagihan menjadi lebih praktis dalam satu kesatuan, sehingga tidak perlu mendatangi beberapa loket pembayaran yang berbeda setiap bulannya dan tidak terjebak dalam antrian panjang yang memakan waktu. Model pengembangan dari aplikasi PPOB ini adalah RAD yang terdiri dari pemodelan bisnis, pemodelan data, pemodelan proses, pembuatan aplikasi dan pengujian.

Kata Kunci: PPOB, Pembayaran Elektronik, Dompet Digital, RAD.

\section{PENDAHULUAN}

Dahulu pengisian pulsa dilakukan dengan mengirim sms kepada server agen pulsa menggunakan telepon selular, pengiriman sms harus sesuai dengan format yang sudah ditentukan oleh tiap server. Namun, kesalahan penulisan format sms sering terjadi dalam sistem pengisian pulsa, yang menyebabkan kegagalan dalam proses pengisian pulsa (Kurniawan, Hijriani, \& Hartawan, 2015). Kesalahan format transaksi baik dalam menginputkan nominal pulsa dan id tagihan pelanggan sehingga berdampak pada biaya dari setiap transaksi yang membengkak karena melalui sms (Wahyudi \& M.T, 2017). Masalah lain yang diangkat yaitu pelanggan PLN sulit untuk mendapatkan informasi mengenai tagihan listriknya (Njatrijani, Widanarti, \& Noveliasari, 2016), meskipun sudah disediakan website yang bisa diakses oleh pelanggan. Namun alamat website tersebut kurang populer. Sedangkan fasilitas lainnya dengan sms juga terdapat kendala, seperti format sms yang harus diingat dan biaya dari sms balasan yang dibebankan kepada pelanggan (Zuriati \& Widyawati, 2018). Untuk mengatasi beberapa kelemahan tersebut dirasa sangat dibutuhkan sebuah perubahan dalam berbagai aspek, salah satunya dalam bentuk penyebaran informasi tagihan pembayaran sehingga informasi dapat dinilai lebih efektif dan efisien (Rahardja, Aini, \& Hardini, 2018). Sehingga masyarakat tidak perlu lagi memeriksa jumlah tagihan melalui website PLN atau datang langsung ke PLN (Agan \& Santoso, 2013). Dan masyarakat tidak lagi terjebak pada antrian yang panjang, tentunya memakan waktu yang lama (Wahyudi \& M.T, 2017).

Saat ini internet telah berkembang pesat dan memberikan banyak kemudahan bagi dunia bisnis. Salah satunya pada bisnis PPOB (Payment Point 
Online Bank). Pada dasarnya, PPOB adalah loket pembayaran online dengan menggunakan fungsi bank. Berbagai jenis tagihan dapat dibayarkan melalui PPOB ini seperti PDAM, BPJS, PLN, telepon, internet, asuransi, tv kabel, kartu kredit, multi finance sampai pada pembelian pulsa prabayar, token listrik dan isi ulang dompet digital. Selain menggunakan fungsi bank, PPOB juga bekerja sama dengan beberapa biller payment provider yang menyediakan koneksi Host-To-Host.

Layanan PPOB yang dikembangkan berjalan pada perangkat mobile berbasis android. Penelitian ini bertujuan untuk memberikan kemudahan dan kenyamanan bagi para pelanggan dalam melakukan berbagai transaksi yang tersedia dalam satu aplikasi. Sehingga diharapkan pelanggan dimana saja dan kapan saja dapat mengetahui infomasi mengenai jumlah tagihan baik itu PLN, telepon, handphone pasca bayar, BPJS kesehatan, PDAM, TV berlangganan dan internet dengan mudah. Serta langsung dapat melakukan pembayaran terhadap tagihan tersebut. Begitupun dengan pembelian pulsa, paket data, token listrik dan pengisian ulang dompet digital seperti OVO dan Gopay menjadi lebih praktis.

\section{BAHAN DAN METODE}

\section{A. Teknik Pengumpulan Data}

Untuk mendapatkan data-data yang menunjang, teknik yang dilakukan adalah metode observasi, yaitu pengamatan secara langsung terhadap kegiatan jual - beli pulsa dan beberapa jenis pembayaran tagihan. Juga dilakukan observasi online dengan cara membandingkan layananlayanan PPOB baik dalam bentuk aplikasi mobile maupun website yang sudah ada sebelumnya. Selanjutnya metode yang digunakan yaitu studi pustaka dengan cara mengumpulkan referensi yang menunjang penelitian ini melalui buku, jurnal, majalah dan sumber lainnya yang mendukung penelitian.

\section{B. Model Pengembangan Sistem}

Penelitian ini menggunakan model pengembangan sistem Rapid Application Development (RAD)(Elyana, Kholil, \& Schaduw, 2019). Tahapan dari model RAD ini yaitu :

1. Pemodelan Bisnis

User harus mendaftarkan diri terlebih dahulu menjadi agen ppob dengan mengisi form registrasi. Pada proses registrasi ini, agen akan mendapatkan nomor rekening virtual, yang diperuntukan untuk pengisian deposit agen. Kemudian untuk masuk kedalam aplikasi ppob, agen diwajibkan untuk login dengan mengisi nomor handphone dan password. Sebelum memulai transaksi pastikan saldo deposit agen sudah terisi. Jika agen ingin melakukan transaksi pembelian pulsa, agen harus memasukkan nomor handphone tujuan pengisian pulsa lalu memilih denom yang diinginkan. Aplikasi akan mengirimkan request dengan format JSON ke aplikasi middle untuk selanjutnya akan diteruskan ke switching tertentu. Aplikasi akan menerima balasan terkait berhasil atau tidaknya transaksi pembelian pulsa tersebut.

Berbeda lagi jika agen akan melakukan pembayaran suatu tagihan. Jika pada pembelian pulsa, request hanya dilakukan sekali pada aplikasi middle namun untuk pembayaran tagihan request dilakukan dua kali. Request pertama disebut inquiry dan request kedua disebut payment. Pertama agen diminta untuk memasukkan nomor pelanggan, kemudian besaran tagihan atas nomor pelanggan tersebut dicek melalui request inquiry. Inquiry response biasanya memuat nama dari pemilik tagihan dan total tagihan yang harus dibayarkan. Setelah itu agen boleh membatalkan atau melanjutkan pembayaran atas tagihannya. Jika agen ingin melanjutkan pembayaran maka aplikasi mengirimkan request kedua ke aplikasi middle. Selanjutnya aplikasi middle akan mengirimkan response sukses atau gagal. terkait berhasil atau gagalnya pembayaran tersebut.

2. Pemodelan Data

Pemodelan data menggunakan Entity Relationship Diagram.

3. Pemodelan Proses

Pemodelan proses dilakukan untuk menjelaskan alur kerja sistem pada transaksi transaksi yang tersedia pada aplikasi PPOB. Pemodelan proses ini dibuat menggunakan diagram aktivitas.

\section{Pembuatan Aplikasi}

Bahasa program yang dipilih yaitu java untuk android menggunakan IDE Android Studio. Dan pertukaran data antara aplikasi PPOB ke aplikasi middle menggunakan format JSON.

5. Pengujian dan Pergantian

Proses pengujian yang dilakukan adalah pengujian kompatibilitas dan pengujian fungsional.

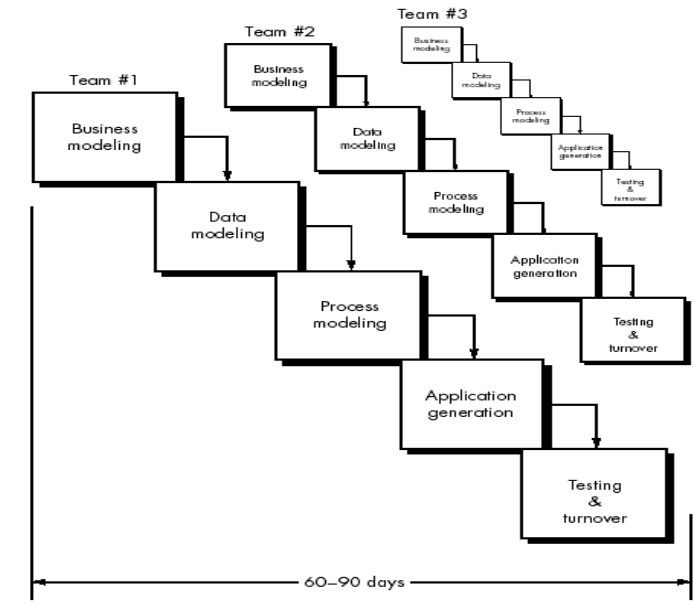

Sumber: (Pressman, 2003) 


\section{Gambar 1. Model RAD \\ HASIL DAN PEMBAHASAN}

\section{Pemodelan Bisnis}

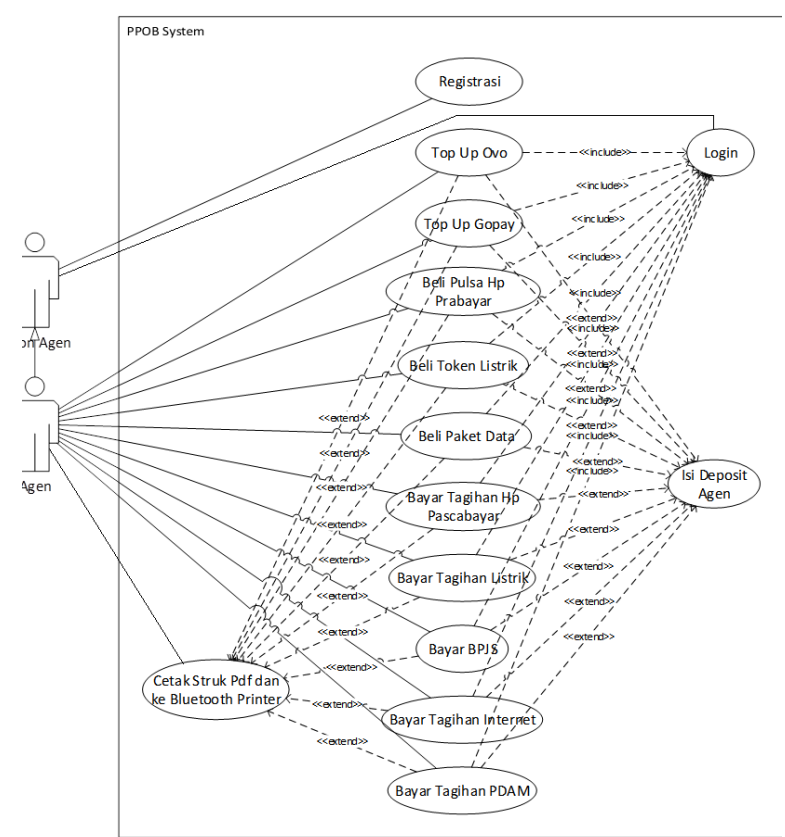

Sumber: (Wasesha \& Frieyadie, 2019)

Gambar 2. Usecase diagram aplikasi PРOB

Penjelasan dari gambar 2 adalah sebagai berikut, User harus mendaftar sebagai agen PPOB terlebih dahulu. Kemudian agen harus login sebelum melakukan transaksi. Transaksi baru bisa dilakukan jika agen telah mengisi deposit agen. Agen dapat melakukan berbagai transaksi seperti topup ovo, gopay, beli pulsa handphone prabayar, token listrik, paket data, bayar tagihan handphone pascabayar, listrik, BPJS, Internet dan PDAM. Setelah melakukan transaksi, agen dapat mencetak struk sebagai bukti pembayaran baik menggunakan printer bluetooth maupun disimpan dalam bentuk format pdf.

2. Pemodelan Data

Pemodelan data pada sistem PPOB seperti terlihat pada gambar 3. Data agen disimpan pada tabel agen, dimana setiap agen memiliki nomor virtual account BNI yang disimpan pada tabel bniva. Setiap agen memiliki level yang berbeda diatur pada tabel levelagent. Total Saldo deposit dari tiap-tiap agen disimpan pada tabel deposit, deposit ini dapat bertambah jika agen melakukan topup sesuai yang tersimpan pada tabel topupdeposit atau dapat berkurang jika agen melakukan transaksi seperti yang tersimpan pada tabel transaksi. PPOB ini terdiri dari banyak produk yang disimpan pada tabel produk, produk tersebut bisa berasal dari mitra-mitra yang berbeda disimpan pada tabel mitra. Dan tiap mitra dapat menetapkan harga dasar untuk produknya, maka disimpan ditabel produkmitra. Managemen fee antar agen diatur pada tabel feeSchema dan feeTrx.

3. Pemodelan Proses

Pada transaksi PPOB terdapat dua jenis proses. Ada transaksi yang hanya satu kali melakukan request ke aplikasi middle kemudian mendapatkan response sukses dan transaksi berakhir. Namun pada jenis kedua yaitu transaksi melakukan dua kali request dan dua kali mendapat response. Untuk request pertama biasa disebut dengan inquiry dan yang kedua disebut payment. Inqury request dilakukan untuk mendapatkan data detail dari nomor id yang dikirim beserta besaran tagihannya. Pada response inqury terdapat tombol untuk melanjutkan atau membatalkan transaksi tersebut. Jika transaksi akan dilanjutkan maka dikirim request yang kedua. Transaksi berakhir ketika response kedua yang didapat sukses. Pada gambar 4 dijelaskan alur dari transaksi yang hanya membutuhkan satu kali request dan satu kali response seperti pada transaksi pembelian pulsa prabayar.

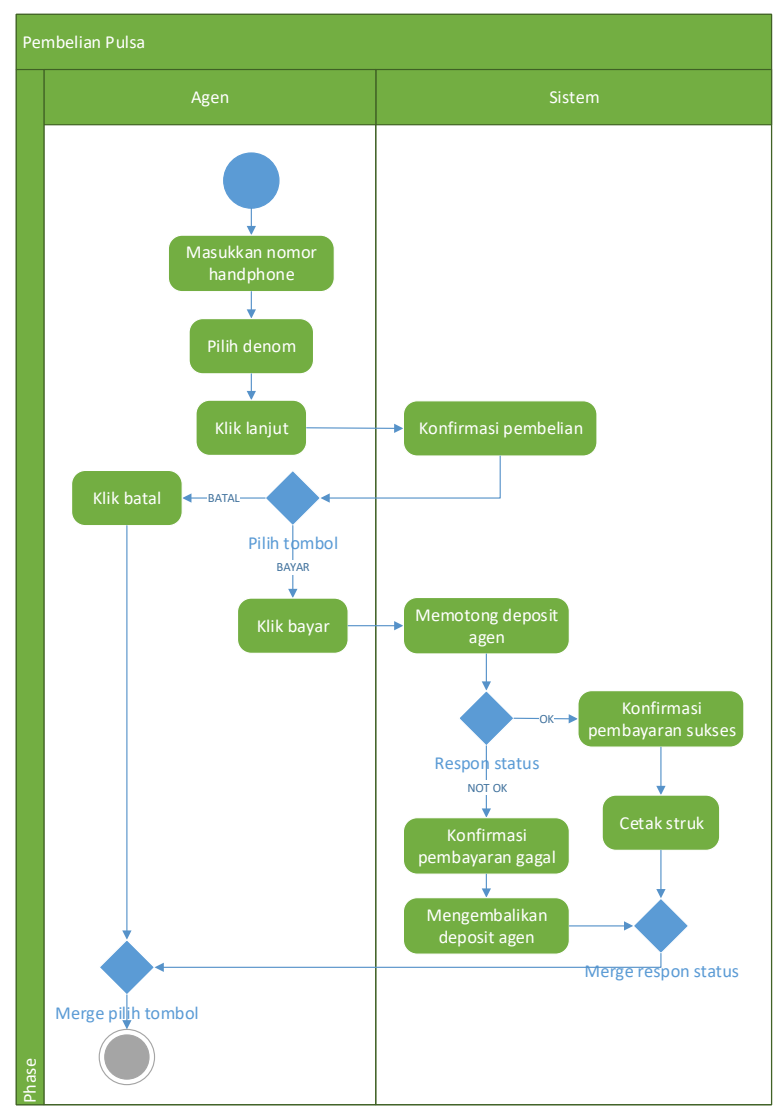

Sumber: (Wasesha \& Frieyadie, 2019)

Gambar 4. Aktivity diagram pembelian pulsa 


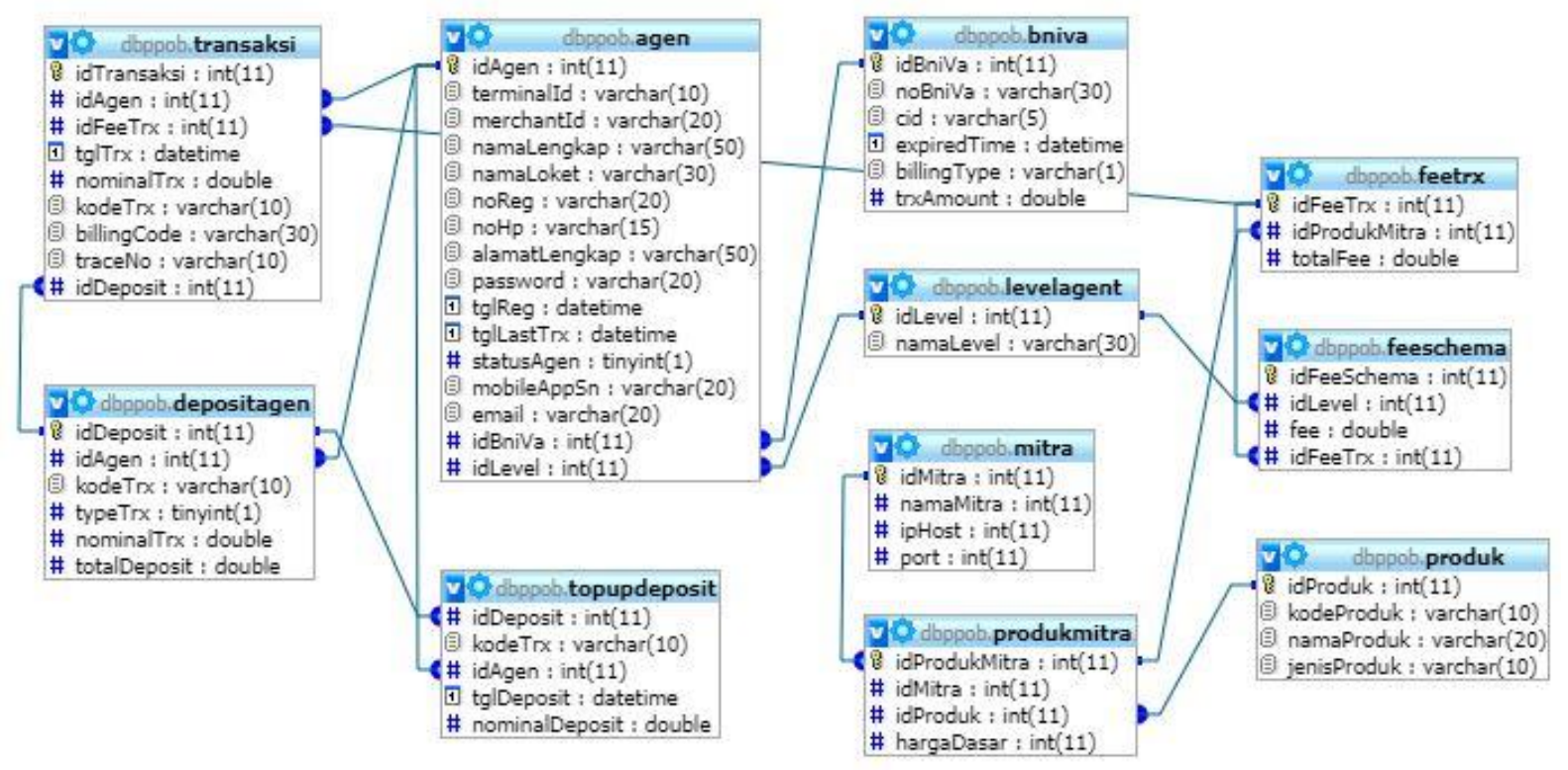

Sumber: (Wasesha \& Frieyadie, 2019)

Gambar 3. Desain Database MySQL

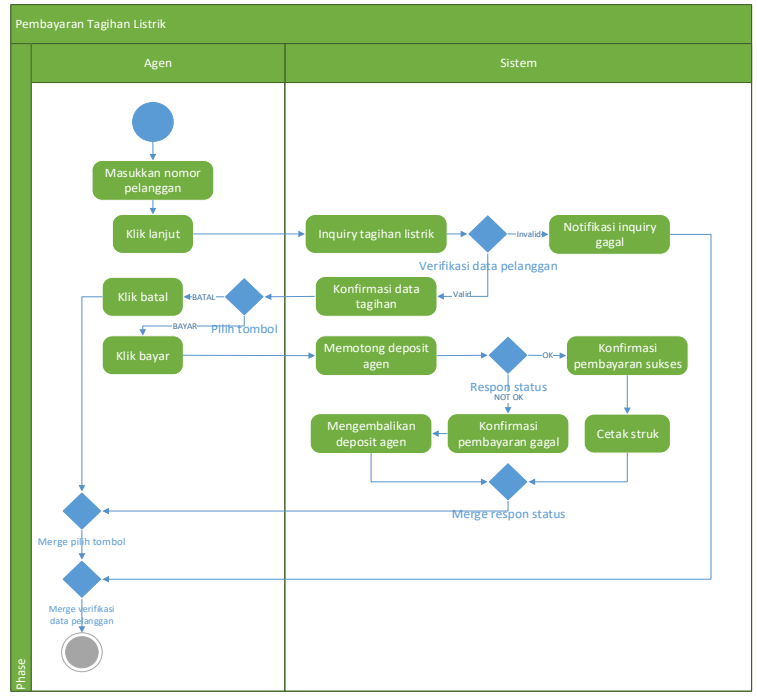

Sumber: (Wasesha \& Frieyadie, 2019)

Gambar 5. Aktivity diagram pengecekan dan pembayaran tagihan listrik

Model proses yang kedua yaitu transaksi yang memerlukan dua kali request dan dua kali response sebagai contoh untuk pembayaran tagihan listrik. Perbedaannya dengan model proses sebelumnya adalah pada pembayaran tagihan listrik ini ada proses untuk pengecekan data pelanggan dan besaran tagihan tertunggak, sehingga dikirimkan request inquiry terlebih dahulu. Setelah mendapatkan response sukses, data detail pelanggan akan ditampilkan beserta besaran tagihannya jika pelanggan menyetujui atas rincian tersebut maka proses dilanjutkan dengan pembayaran. Alur sistemnya seperti gambar 5 .
4. Pembuatan Aplikasi

Pembuatan aplikasi front-end ini menggunakan bahasa pemrograman java untuk android. Setiap request yang dikirimkan ke aplikasi middle menggunakan API dengan format request dan response berupa JSON.

a) Halaman Login

Login agen dapat dilakukan dengan memasukkan nomor handphone dan password. Tampilan loginnya seperti terlihat pada gambar 6 .

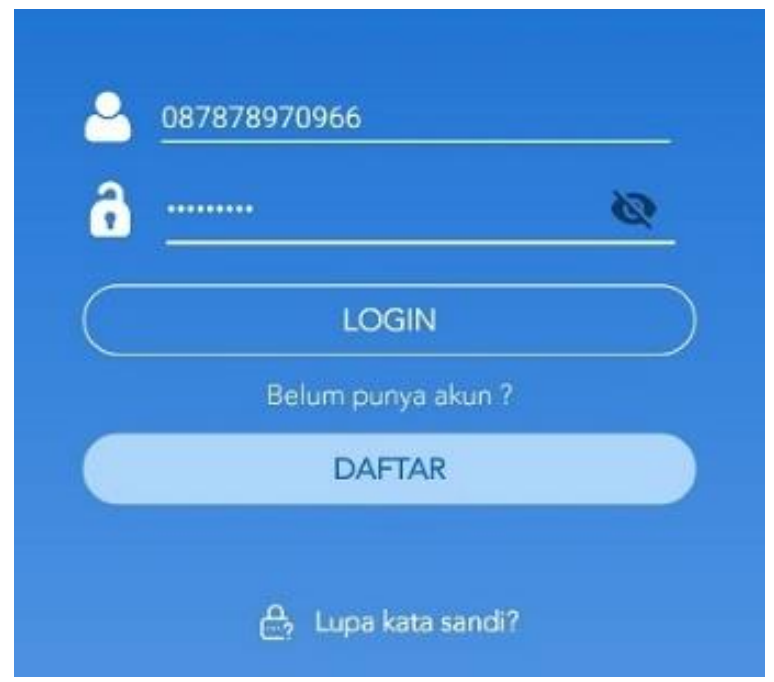

Sumber: (Wasesha \& Frieyadie, 2019)

Gambar 6. Halaman login

b) Halaman Pendaftaran Agen

Untuk menjadi agen PPOB maka diharuskan untuk melakukan pendaftaran terlebih dahulu, seperti terlihat pada gambar 7 . 


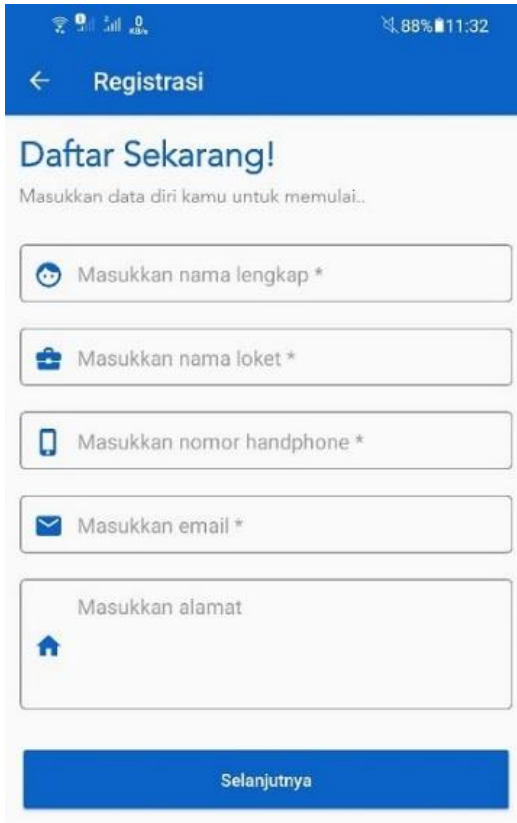

Sumber: (Wasesha \& Frieyadie, 2019)

Gambar 7. Halaman pendaftaran agen

c) Halaman Home

Setelah agen berhasil login maka ia akan dibawa ke halaman home. Pada halaman home terdapat saldo dari agen, beberapa kategori transaksi dan juga ada daftar artikel. Gambar 8 merupakan tampilan dari halaman home ini.

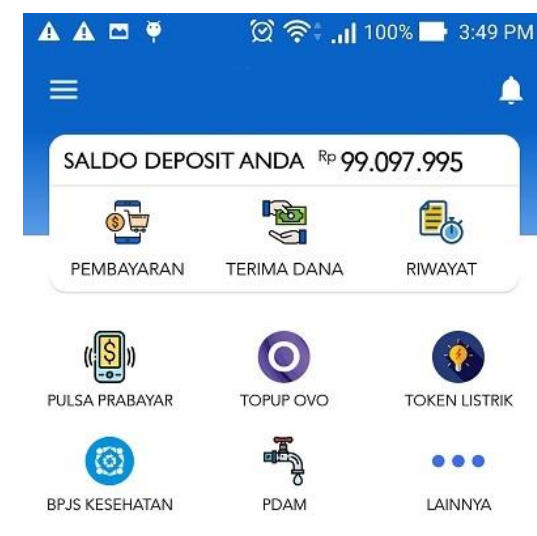

ARTIKEL

Lihat Semua >

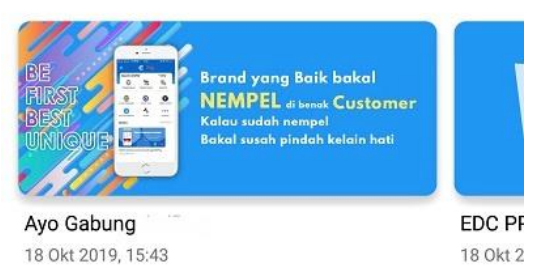

Sumber: (Wasesha \& Frieyadie, 2019)

Gambar 8. Halaman home

d) Halaman Semua Kategori

Setelah dari halaman home lalu diklik icon titik tiga (lainnya), maka akan dibawa ke halaman semua kategori. Halaman ini berisi semua kategori transaksi yang dapat dilakukan oleh agen. Terlihat pada gambar 9.

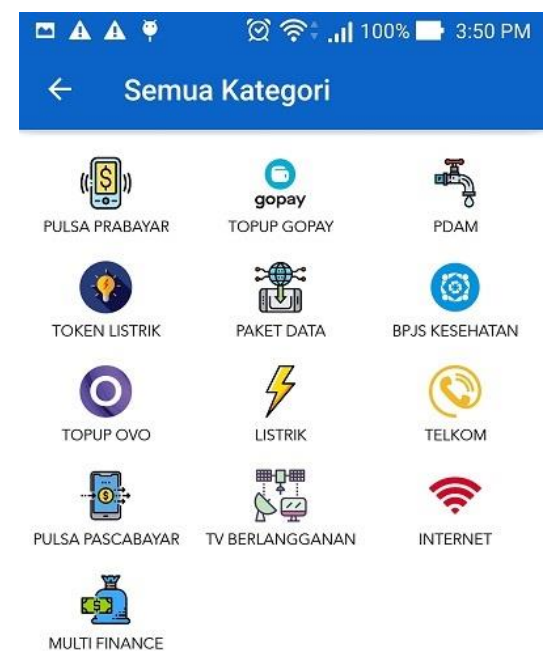

Sumber: (Wasesha \& Frieyadie, 2019)

Gambar 9. Halaman semua kategori

e) Halaman Pembelian Pulsa

Halaman ini tampil setelah agen memilih kategori "PULSA PRABAYAR". Untuk memulai transaksi isi terlebih dahulu nomor handphone yang ingin dituju baik dilakukan dengan manual maupun dengan mengklik icon kontak disebelah kanan dari nomor handphone. Setelah itu agen harus memilih denom yang diinginkan kemudian menekan tombol "LANJUT". Seperti yang ditampilkan pada gambar 10 .

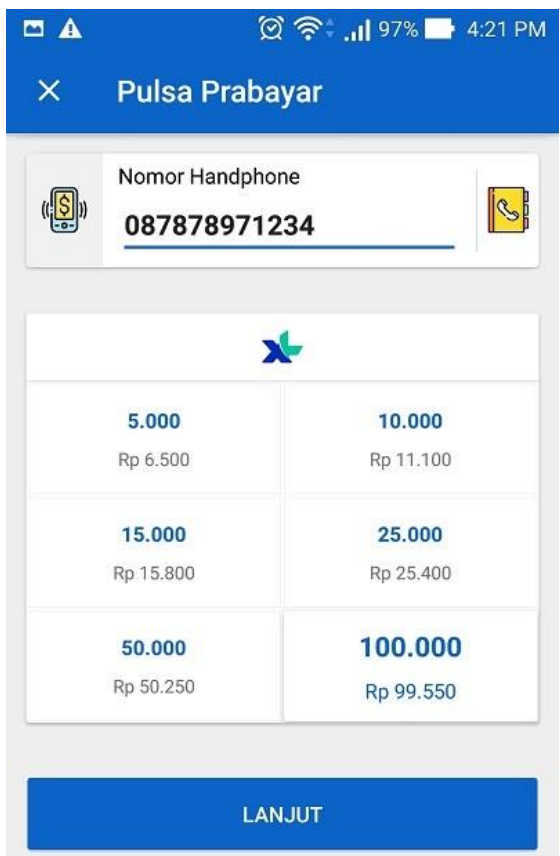

Sumber: (Wasesha \& Frieyadie, 2019)

Gambar 10. Halaman pembelian pulsa 
f) Notifikasi Konfirmasi Pembelian

Notifikasi ini tampil untuk memastikan kembali apakah agen akan membeli pulsa untuk nomor handphone dan dengan denom tersebut. Jika agen sudah yakin untuk melanjutkan transaksi ini maka ia akan menekan tombol "BAYAR". Notifikasi yang ditampilkan seperti gambar 11 .

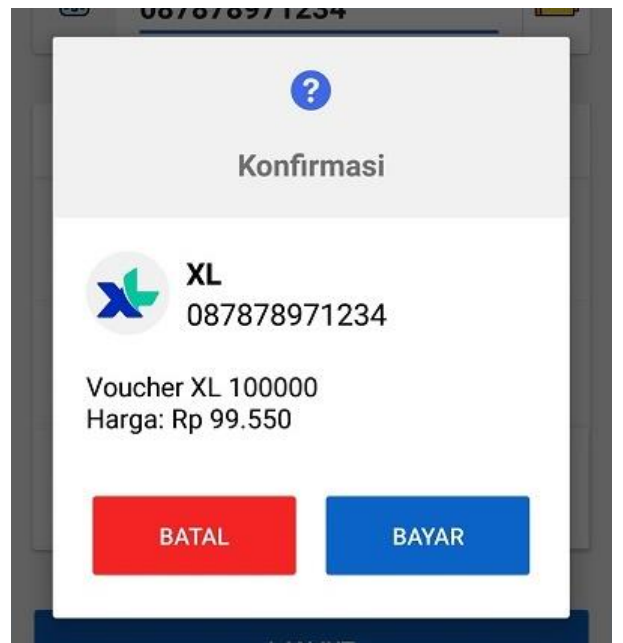

Sumber: (Wasesha \& Frieyadie, 2019)

Gambar 11. Halaman konfirmasi pembelian

Pada gambar 11, ketika tombol "BAYAR" ditekan maka aplikasi akan mengirimkan request pada aplikasi middle berupa format JSON seperti pada gambar 12 .

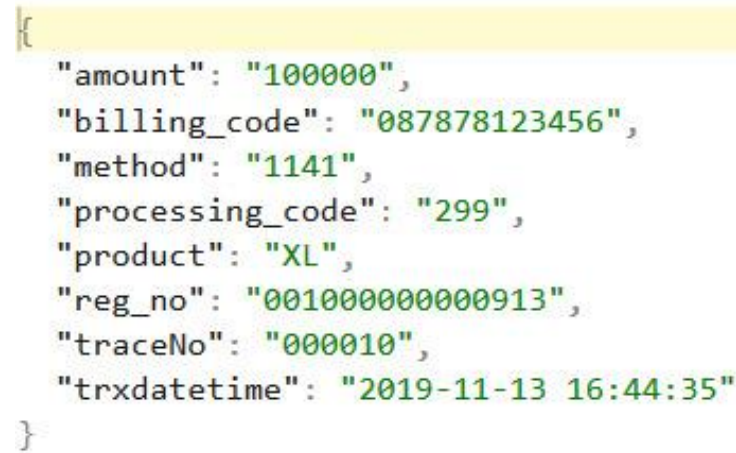

Sumber: (Wasesha \& Frieyadie, 2019)

Gambar 12. Json request dari pembelian pulsa

Penjelasan gambar 12 seperti berikut, billing_code adalah nomor handphone tujuan dari pengisian pulsa, amount merupakan denom yang dipilih, product adalah jenis provider dari nomor handphone yang dimasukkan dan reg_no adalah nomor registrasi dari agen.

Kemudian aplikasi middle akan menanggapi request tersebut dengan mengirimkan response seperti gambar 13. Penjelasannya sebagai berikut, billAmount adalah jumlah nominal yang dibebankan atas transaksi ini, customer_data adalah data yang nanti akan di parsing lagi oleh aplikasi front-end untuk ditampilkan pada halaman pembelian pulsa berhasil, terdapat juga saldo awal agen sebelum melakukan transaksi dan saldo akhir setelah melakukan transaksi ini.

I

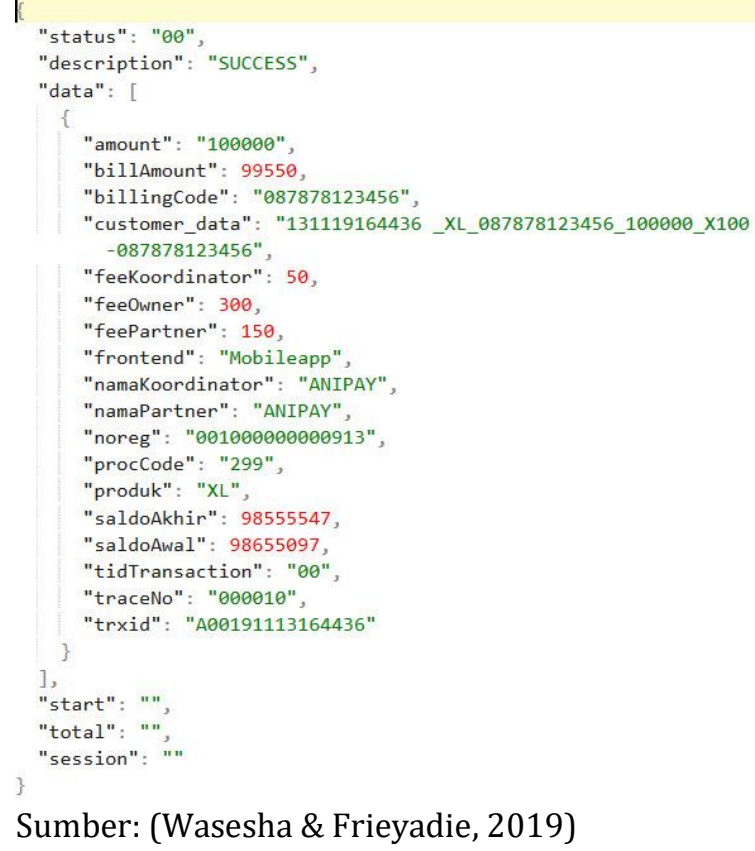

g) Halaman Pembelian Pulsa Berhasil

Jika transaksi pembelian pulsa berhasil dilakukan maka aplikasi akan menampilkan halaman seperti pada gambar 14 .

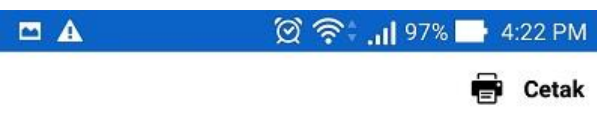

\section{TRANSAKSI SUKSES}

Tanggal: 13/11/2019 16:22:02

$\mathrm{XL}$

$\begin{array}{ll}\text { VOUCHER } & : \text { XL } \\ \text { DENOM } & : 100.000 \\ \text { NO PONSEL } & : 087878971234 \\ \text { TOTAL BAYAR } & : \text { Rp } 99.550 \\ \text { KODE TRX } & : \\ \text { A00191113162159 }\end{array}$

\section{TUTUP}

Sumber: (Wasesha \& Frieyadie, 2019)

Gambar 14. Halaman pembelian pulsa berhasil

h) Halaman Struk Pulsa Format Pdf

Struk pembelian pulsa dapat dicetak langsung dengan printer bluetooth atau dikonversi kedalam format pdf seperti pada gambar 15 . 


\section{$\mathbf{A}$}

'Q' วิ .

\section{$\leftarrow$ pulsa_prepaid.pdf $\quad$ at :}

mบ РP९:

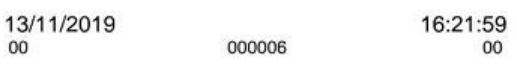

PULSA XL

NO. PONSEL : 087878971234

DENOM : Rp 100.000

REF : : $100-087878971234$

Simpan tanda terima ini sebagai bukti transaksi yang sah

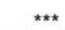

Sumber: (Wasesha \& Frieyadie, 2019)

Gambar 15. Halaman struk pulsa format pdf

5. Pengujian dan Pergantian

Pengujian yang dilakukan terdiri dari dua tahap yaitu pengujian kompatibilitas dan pengujian fungsional.

a) Pengujian kompatibilitas

Aplikasi ini diinstal ke beberapa perangkat android dengan spesifikasi yang berbeda untuk memastikan aplikasi dapat berjalan dengan baik. Berikut tabel hasil pengujian kompatibilitas:

Tabel 1. Hasil pengujian kompatibilitas

\begin{tabular}{|c|c|c|c|c|}
\hline & Test 1 & Test 2 & Test 3 & Test 4 \\
\hline Merk & $\begin{array}{l}\text { Asus } \\
\text { Zenfone } 5\end{array}$ & $\begin{array}{l}\text { Asus } \\
\text { Zenfone } \\
2\end{array}$ & $\begin{array}{l}\text { Xiaomi } \\
\text { Redmi } 5 \\
\text { plus }\end{array}$ & $\begin{array}{l}\text { Samsun } \\
\text { g Galaxy } \\
\text { J7 Pro }\end{array}$ \\
\hline CPU & SDM636 & $\begin{array}{l}\text { Intel } \\
\text { Atom } \\
\text { Z3580 }\end{array}$ & $\begin{array}{l}\text { SDM62 } \\
5\end{array}$ & $\begin{array}{l}\text { Exynos } \\
7870\end{array}$ \\
\hline RAM & $4 \mathrm{~GB}$ & $4 \mathrm{~GB}$ & $3 \mathrm{~GB}$ & $3 \mathrm{~GB}$ \\
\hline Layar & $6.2 \mathrm{in}$ & 5.5 in & $5.9 \mathrm{in}$ & 5.5 in \\
\hline $\begin{array}{l}\text { Versi } \\
\text { Android }\end{array}$ & 9 & 5 & 7 & 9 \\
\hline Hasil & $\begin{array}{l}\text { Berjalan } \\
\text { dengan } \\
\text { baik }\end{array}$ & $\begin{array}{l}\text { Berjalan } \\
\text { dengan } \\
\text { baik }\end{array}$ & $\begin{array}{l}\text { Berjalan } \\
\text { dengan } \\
\text { baik }\end{array}$ & $\begin{array}{l}\text { Berjalan } \\
\text { dengan } \\
\text { baik }\end{array}$ \\
\hline
\end{tabular}

Sumber: (Wasesha \& Frieyadie, 2019)

b) Pengujian fungsional
Pengujian dilakukan pada setiap fitur yang ada, yang mencakup login, pendaftaran, lupa password, semua transaksi, percetakan struk sampai historikal dari transaksi-transaksi tersebut. Langkah-langkah pengujian ini dengan memberikan beberapa input positif ataupun negatif yang bertujuan untuk memastikan output dari aplikasi sudah sesuai dengan yang diharapkan. Tabel 2 adalah hasil dari pengujian halaman pendaftaran:

Tabel 2. Script test case halaman pendaftaran

\begin{tabular}{|c|c|c|c|}
\hline No & Skenario test & $\begin{array}{l}\text { Hasil yang } \\
\text { diharapkan }\end{array}$ & $\begin{array}{l}\text { Hasil } \\
\text { aktual }\end{array}$ \\
\hline 1 & $\begin{array}{l}\text { Nama lengkap } \\
\text { dikosongkan lalu } \\
\text { tekan tombol } \\
\text { "Selanjutnya". }\end{array}$ & $\begin{array}{l}\text { Kolom nama } \\
\text { lengkap } \\
\text { berwarna } \\
\text { merah dan } \\
\text { terdapat notif } \\
\text { "nama lengkap } \\
\text { harus diisi" }\end{array}$ & Sesuai \\
\hline 2 & $\begin{array}{lr}\text { Input nama } \\
\text { lengkap kurang } \\
\text { dari 3 karakter. } \\
\text { Lalu tekan } \\
\text { tombol } \\
\text { "Selanjutnya". } \\
\text { Contoh data: Di }\end{array}$ & $\begin{array}{l}\text { Kolom nama } \\
\text { lengkap } \\
\text { berwarna } \\
\text { merah dan } \\
\text { terdapat notif } \\
\text { "nama lengkap } \\
\text { kurang dari tiga } \\
\text { karakter" }\end{array}$ & Sesuai \\
\hline
\end{tabular}

\begin{tabular}{|c|c|c|c|}
\hline 3 & $\begin{array}{l}\text { Input nama } \\
\text { lengkap lebih } \\
\text { dari } 3 \text { karakter. } \\
\text { Lalu tekan } \\
\text { tombol } \\
\text { "Selanjutnya". } \\
\text { Contoh data: } \\
\text { Dian }\end{array}$ & \begin{tabular}{lr} 
Pada & kolom \\
nama lengkap \\
tidak berwarna \\
merah dan tidak \\
terdapat & notif \\
error, namun \\
pada & kolom \\
nama & loket \\
berwarna & \\
merah & dan \\
terdapat notif & "nama loket \\
\multicolumn{2}{c}{ harus diisi". }
\end{tabular} & Sesuai \\
\hline 4 & $\begin{array}{l}\text { Input nama } \\
\text { loket, lalu tekan } \\
\text { tombol } \\
\text { "Selanjutnya". } \\
\text { Contoh data: } \\
\text { Dian Cellular }\end{array}$ & $\begin{array}{lr}\text { Kolom nama } \\
\text { loket } & \text { tidak } \\
\text { berwarna } & \\
\text { merah dan } & \text { tidak } \\
\text { terdapat } & \text { notif } \\
\text { error namun } & \text { nada } \\
\text { polom } \\
\text { nomor } \\
\text { handphone } \\
\text { berwarna } \\
\text { merah } \\
\text { terdapat notif } \\
\text { "nomor }\end{array}$ & Sesuai \\
\hline
\end{tabular}




\begin{tabular}{|c|c|c|c|}
\hline & & $\begin{array}{l}\text { handphone } \\
\text { harus diisi". }\end{array}$ & \\
\hline 5 & $\begin{array}{l}\text { Input nomor } \\
\text { handphone, lalu } \\
\text { tekan tombol } \\
\text { "Selanjutnya". } \\
\text { Contoh data: } \\
087878123456\end{array}$ & $\begin{array}{l}\text { Pada kolom } \\
\text { nomor } \\
\text { handphone tidak } \\
\text { berwarna } \\
\text { merah dan tidak } \\
\text { terdapat notif } \\
\text { error namun } \\
\text { pada kolom } \\
\text { email berwarna } \\
\text { merah dan } \\
\text { terdapat notif } \\
\text { error "email } \\
\text { harus diisi". }\end{array}$ & Sesuai \\
\hline 6 & $\begin{array}{l}\text { Input email tidak } \\
\text { sesuai format, } \\
\text { lalu tekan } \\
\text { tombol } \\
\text { "Selanjutnya". } \\
\text { Contoh data: } \\
\text { dian@y }\end{array}$ & $\begin{array}{lr}\text { Kolom } & \text { email } \\
\text { berwarna } & \\
\text { merah } & \text { dan } \\
\text { terdapat } & \text { notif } \\
\text { "format } & \text { email } \\
\text { salah" } & \end{array}$ & Sesuai \\
\hline 7 & $\begin{array}{l}\text { Input email } \\
\text { dengan format } \\
\text { yang benar, lalu } \\
\text { tekan tombol } \\
\text { "Selanjutnya". } \\
\text { Contoh data: } \\
\text { dian@yahoo.com }\end{array}$ & $\begin{array}{l}\text { Tampil halaman } \\
\text { kode verifikasi. }\end{array}$ & Sesuai \\
\hline
\end{tabular}

Sumber: (Wasesha \& Frieyadie, 2019)

\section{KESIMPULAN}

Dengan adanya aplikasi PPOB berbasis android ini siapapun dapat melakukan transaksi pembelian pulsa dengan mudah. Tidak ada lagi kesalahan dalam penulisan format sms untuk mengirimkan request ke server agen karena pengguna hanya tinggal memasukkan nomor handphone yang dituju saja. Keuntungan lainnya bagi pelanggan PLN adalah dapat kapan saja mengecek besaran tagihan listriknya dan melakukan pembayaran terhadap tagihan tersebut. Berbagai tagihan dapat dibayarkan pada satu aplikasi, tidak perlu lagi mendatangi masingmasing loket pembayaran yang berbeda setiap bulannya. Aplikasi PPOB ini merupakan cara pembayaran yang lebih aman, efektif dan efisien karena membayar berbagai jenis tagihan dapat dilakukan sendiri melalui smartphone.

\section{REFERENS}

Agan, L., \& Santoso, P. (2013). Pembuatan Aplikasi Cek Tagihan Listrik Berbasis Android. Jurnal Dimensi Teknik Elektro, 1(1), 24-28.
Elyana, I., Kholil, I., \& Schaduw, F. E. (2019). RANCANG BANGUN SISTEM INFORMASI MANAJEMEN DISPOSISI SURAT MENYURAT DENGAN MENGGUNAKAN MODEL RAD (RAPID APPLICATION DEVELOPMENT). Jurnal Riset Informatika, 1(2), 107-112. https://doi.org/10.34288/JRI.V1I2.37

Kurniawan, D., Hijriani, A., \& Hartawan, F. T. (2015). Rancang Bangun Aplikasi Agen Pulsa Elektronik Bebasis Android (Studi Kasus Distributor Pulsa Maxrefil). Komputasi, 3(2), 144-153.

Njatrijani, R., Widanarti, H., \& Noveliasari, N. (2016). Perlindungan Hukum Bagi Konsumen terhadap Penggunaan Jasa Listrik Pascabayar dan Jasa Listrik Prabayar pada PT. Pln (Persero) di Kota SemarangNo Title. Diponegoro Law Review, 5(3). Retrieved from https://ejournal3.undip.ac.id/index.php/dlr/ article/view/12120

Pressman, R. S. (2003). Software Engineering A Practitioner's Aproach Fifth Edition. Singapore: Mc Graw Hill.

Rahardja, U., Aini, Q., \& Hardini, M. (2018). PENERAPAN SOFTWARE AKUNTANSI ONLINE SEBAGAI PENUNJANG PENCATATAN LAPORAN KEUANGAN. SISFOTENIKA, 8(2), 176-187.

Wahyudi, A. M., \& M.T, R. (2017). Aplikasi Payment Point Online Bank (PPOB) Menggunakan Web Service di PT. Sukses Mitra Mandiri Berbasis Android. Jurnal Ilmiah Komputer dan Informatika (KOMPUTA).

Wasesha, D. A., \& Frieyadie, F. (2019). Laporan Akhir Penelitian Mandiri. Jakarta.

Zuriati, Z., \& Widyawati, D. K. (2018). Android based Agriculture products price information system. Jurnal Ilmiah ESAI, 8(2), 173-183. https://doi.org/10.25181/ESAI.V8I2.963 